\title{
Temporary Migration Programmes: the Cause or Antidote of Migrant Worker Exploitation in UK Agriculture
}

\author{
Erica Consterdine $^{1}$ (D) $\cdot$ Sahizer Samuk ${ }^{2}$
}

Published online: 1 June 2018

(C) The Author(s) 2018

\begin{abstract}
The referendum result in Britain in 2016 and the potential loss of EU labour in the advent of a 'hard Brexit' has raised pressing questions for sectors that rely on EU labour, such as agriculture. Coupled with the closure of the long-standing Seasonal Agricultural Scheme in 2013, policymakers are grappling with how to satisfy on the one hand employer demands for mobility schemes, and on the other public demands for restrictive immigration policies. Labour shortages in agriculture transcend the immigration debate, raising questions for food security, the future of automation and ultimately what labour market the UK hopes to build. Temporary migration programmes have been heralded as achieving a triple win, yet they are rightly criticized for breeding bonded labour and exploitation. In lieu of a dedicated EU labour force, agricultural employers are calling for the establishment of a new seasonal scheme. In this paper, we explore whether the absence of a temporary migration programme resolves the potential exploitation of migrant workers. We argue that the absence of a temporary migration programme (TMP) is not an antidote to migrant exploitation, and that a socially just TMP which is built around migrant agency may be the most palpable solution.
\end{abstract}

Keywords Temporary migration $\mid \cdot$ Seasonal agricultural work $\cdot$ Integration $\cdot$ Triple-win migration scenario $\cdot$ UK labour market $\cdot$ Brexit

Erica Consterdine

e.consterdine@sussex.ac.uk

Sahizer Samuk

sahsamuk@gmail.com

1 Department of Geography, University of Sussex, Arts C, Falmer BN1 9SJ, UK

2 Maison des Sciences Humaines, Université du Luxembourg, 11, Porte des Sciences, MSH, E02 15-010, L-4366 Esch-sur-Alzette, Luxembourg 


\section{Introduction}

The slogan that 'there is nothing more permanent than temporary foreign workers' (Martin 2006) has been a popular phrase to express the perceived failures of temporary migration programmes (TMPs). Whilst TMPs particularly agricultural programmes are typically recognized as being exploitative (Lenard and Straehle 2012; Strauss and Mcgrath 2017), as global labour market needs have evolved, there has been some resurgence in TMPs and the advantages these programmes can bring (Gilbert 2014). TMPs purportedly achieve the so-called triple-win outcomes: the host country can meet labour market demands whilst appeasing electoral concerns over permanent settlement; the sending country benefits from both remittances and skills transfer/brain gain from migrants acquiring skills in the destination state and transferring these skills on return; and the migrants themselves benefit by a mechanism which provides people from low-income countries with better access to labour markets in high-income states. Ultimately, TMPs are pitched as the inbetween solution which satisfies both the 'no borders' and 'no migrants' arguments (Ruhs and Martin 2008, p. 260).

TMPs could then be an attractive solution for the UK government following the shock referendum result in 2016. In the face of a possible 'hard Brexit' in 2019 and the consequential end of free movement following the transition period, the political establishment is grappling with how to satisfy both public and business demands for restrictive and expansive approaches to immigration respectively. Pressing questions remain as to how sectors, such as agriculture, that rely heavily on EU labour will survive in lieu of a dedicated labour immigration scheme. A National Framers Union (NFU) providers survey recently revealed that $47 \%$ of providers were already unable to meet labour demands in 2017 despite free movement continuing (NFU 2017). In a BBC survey in 2017, $78 \%$ of respondents said that recruitment had been more difficult in the past year (Simpson 2017). The anticipated labour market shortages in agriculture have been compounded by the closure of the 70-year long Seasonal Agricultural Workers Scheme (SAWS) in 2013-a turning point in its own right. The seasonal labour shortages in agriculture have led the Environmental, Food and Rural Affairs Committee to conclude that farming and horticulture businesses 'have big problems retaining labour' and that 'the challenge will become a crisis if the government do not swiftly take measures' (House of Commons 2017a, b, 195WH).

Labour shortages in the agricultural sector have consequences beyond immigration; food security could be threatened, as imports will become the increasingly dominant source of fresh food for the UK. This will in turn raise costs for producers that will be subsidized through higher food prices for consumers (Sumption 2017). As a result, the government has insinuated that they may seek to establish a new agricultural scheme for labour migrants post Brexit (Gove quoted in Horticulture Week 2017), yet this is far from a certainty. The government's dilemma - to re-establish an agricultural migrant scheme or circumvent ways around migrant labour shortages by increasing native employment, automation and possibly offshoring - becomes wider questions regarding the worth of work and what kind of labour market the UK hopes to build. It is thus a fitting time to reflect on the policy evolution of the SAWS, and more importantly, the impact and repercussions of its closure both economically and socially as UK employers anticipate the loss of EU labour in post-Brexit Britain. 
Using the UK SAWS as a case study, we analyse the losses and gains from closing a TMP. Based on desk research and stakeholder interviews, we assess whether the absence of a TMP acts as an antidote to exploitation or a preventative. We argue that whilst the loss of EU labour may force the sector to improve working conditions, closing a TMP can have the adverse effect of a triple loss and exacerbate exploitation. We contend that a TMP underscored and built around migrant agency is a more socially just response than terminating a TMP.

We begin the article by a brief literature review on temporary migration policies and outline our methodology. After summarising the policy evolution of SAWS and its termination, we assess and analyse the impacts of closing SAWS.

\section{Temporary Migration Policies: Rights, Conditionality and Debates}

Temporary labour migration policies have been criticized for a number of reasons, including the lack of rights granted, and in particular the lack of right/route to permanency and citizenship. The research on TMPs and TMWs focused more on the precarious status of the TMWs (Bernhard et al. 2009) than the possible alternative pathways to TMPs (Castles 2006; Ruhs 2006). The example of the UK gives us an opportunity to evaluate the repercussions of the absence of a temporary programme, and whether this result solves the rights-based arguments against such programmes.

Previous research has analysed various aspects of TMPs and SAWS specifically, including the practices of employers and their perception of temporary migrant workers (TMWs) (Findlay et al. 2013; Scott 2013), migrants' agency (Cook et al. 2010; Spencer et al. 2007) and role of the recruitment agencies and intermediaries in seasonal work (Rogaly 2008). We seek to build on these bodies of work by drawing on Carens (2013) framework. Carens (2013, p.121) questions whether it is acceptable for democratic states to admit people only temporarily, 'under what conditions?'

Goldring (2014, p.223) claims that temporariness has been considered in terms of insufficient and inequitable rights, blocked membership and temporality and argues that there are three possible policy solutions to overcome the exploitative potential of TMPs: '1) changing regulations to reduce exploitation and vulnerability 2) reducing the amount of time people spend in temporary situations or the number of people in them, or expanding pathways to permanence 3) eliminating temporary worker programs.'. Other scholars have similarly suggested that adapting TMPs by granting further rights is the more practical solution to terminating TMPs altogether (Lenard and Straehle 2012).

It is well acknowledged that TMPs are opportunistic for states to both meet labour market demands whilst limiting settlement. However, an overlooked facet of this debate is whether TMPs truly benefit the migrants or not, and whether the termination of programmes on the basis of potential exploitation achieves better outcomes for workers. On this, the research is mixed. Much research has illustrated how TMPs are not beneficial for the migrant because even the best examples fall short of the international best practice standards (Hennebry and Preibisch 2012). However, Goldring (2014, p. 219) argues that temporariness is not unequivocal with precariousness, conditionality of precarious status or inequality, whilst at the same time 'permanence does not always mitigate insecurity and social exclusion'. Conditionality (Landolt and Goldring 2015, p. 857) is key for building a socially 
just TMP, which refers the trajectories of non-citizenship (including legal status) and how it is shaped via social learning, migrants' agency and policy enforcement at many levels, 'denoting the material and discursive conditions that must be met to acquire and exercise the formal or substantive right to remain'. Raghuram (2014) also underlines how migrants were required to inhabit temporariness and learnt to benefit from it as agents. TMPs can then bring opportunities for migrant workers, both structurally (financially) and from an agency perspective (entrepreneurship and skills gains).

Gilbert (2014) and others (Bauder 2006) argue that TMWs are rendered vulnerable because of their status because 'temporariness puts limits on their access to health care, social programs and labour protections' (Gilbert 2014, p.153). However, Carens (2013) posits that in the absence of TMPs, some migrants will come and work irregularly in any case and will have no rights rather than limited. Thus, in the absence of sponsored programmes, irregularity as a status can dominate the lives of some migrant workers. De Lange and Sarah van (2014, p.143) similarly found in their research that 'all participants in the ethnographic component of this research were of the opinion that even a circular migration regime would be preferable to the current exclusion of "lowskilled" migrant workers from regularized migration status'.

Our position therefore is that it is not that TMPs that should be abandoned but the temporariness should be equally supporting the agency of the migrant workers (Goldring and Landolt, 2011) as much as it supports the employers' beneficial condition. This should be based on an agreement between the host and the origin country that enables temporariness to become an opportunity and freedom from working in precarious conditions.

Methodologically, the paper is based on explorative process tracing conducted through semi-structured interviews between 2011 and 2016 with stakeholders in triangulation with document analysis. We conducted 20 interviews with stakeholders, which included employers, employer associations, trade unions, relevant government (national and local) representatives and migrant right organisations. Our desk research, which worked to triangulate and validate findings from the interviews, involved a three-stage analysis of documents including newspaper articles, press releases, policy documents and relevant research conducted by organisations. We now move to a review to surmise both the evolution and termination of SAWS, and the current climate following the referendum result in 2016.

\section{Policy Evolution of SAWS}

The SAW programme was established in 1945 following the War and the resulting shortage of British manpower, as a cultural exchange scheme to encourage young, predominantly agricultural, students from across Europe to work in agriculture and horticulture during the peak seasons. However, over time, the scheme evolved as a tool to meet labour demand in the agricultural sector more generally, although 'the idea was still to develop cross cultural understanding and friendships across borders' (interview Concordia 2015). The SAWS was modified over the years, but it was in 1990 when the scheme became quota-based, beginning with an annual quota of 5500 workers. Before the closure of the scheme in 2013, SAWS had reached a quota of 21,250 , a fourfold increase from the original 1990 quota. 
Whilst in 2004, the UK government did not initiate transitional measures on nationals of the A8 countries - thereby giving unfettered access to the UK labour market for these citizens - the UK government imposed full transitional controls (7 years) on Bulgaria and Romania following the 2007 accession with an 'intention to phase it [SAWS] out as EU labour markets expanded' (Harper 2013). Thus, as a concession to the new accession states of Bulgaria and Romania (A2), the government stipulated that only A2 migrants could work on the SAWS from 2008, and that is why the student restriction was abandoned, which at the time the industry objected to a lot because they would not be from an agricultural background but the sector got used to that and they just made their recruitment process more rigorous (NFU policy officer, interview 2011). In 2013, when the scheme was closed, two thirds of the seasonal labour force remained from the A2 (NFU 2017).

Different actors from both sending and receiving countries were involved in the operation of SAWS. In terms of implementation, one of the most important sets of actors were the operators, characteristic of the trend towards 'outsourcing' migration controls to private actors. Operators were responsible for recruiting and processing applications, ensuring that farmers provided suitable accommodation and adhere to regulations around work rights such as the minimum wage, and ultimately for the liability of those workers who had breached their visa terms and conditions. Without operators' permission, workers could not switch to another farm site creating 'bonded labour' (Rogaly 2008). Hence, operators formed the control mechanism for the lives of the workers. Nine operators managed the SAWS on behalf of the UK Visas and Immigration Directorate (formerly known as the UK Border Agency). However, SAWS was, in the main, an industry-run scheme with only a 'light touch' from the Home Office in terms of enforcement because there was no right to remain. Overall SAWS was deemed a success being regarded as a 'well managed scheme' with a high return rate (interview HOPS solution 2016).

Although SAWS was regarded as successful scheme, the closure in 2013 was not unexpected. As the Conservative-led Coalition government entered office in 2010, one of the first orders of the day was to put measures in place to achieve the Conservative manifesto pledge of reducing net migration from the hundreds of thousands to the tens of thousands, 'so that people have confidence in the system' and to 'ensure cohesion and protect our public services' (HM Government 2010: 21). Numerous policy channels were tightened (Gower 2016), including TMPs.

A position paper by the Labour Providers Association in 2012 raised a number of questions for the rationale for the SAWS questioning whether there was a need for the scheme, whether SAWS represented unfair competition to labour providers through tax benefits and 'whether a scheme which is basically "bonded labour" is acceptable' (Labour Providers 2012). Later in 2012, the government called for the Migration Advisory Committee (MAC) — an independent, non-departmental public body that advises the government on migration issues - to assess the impact on the agriculture and horticulture sectors if SAWS was terminated. The MAC concluded that a reduction in labour in the short term would have a modest impact but that in the medium term farmers were likely to experience increasing difficulties in sourcing required labour (MAC 2013, 12).

Following the MAC report, in order to cut net migration drastically and 'break the link' between temporary and permanent migration, the government proceeded with the 
planned closure of the SAWS in December 2013 to coincide with transitional controls lapsing for A2 citizens from Bulgaria and Romania in January 2014. The government's view was that 'at a time of unemployment in the UK and the European Union there should be sufficient workers from within those labour markets to meet the needs of the horticultural industry' (Harper 2013), and moves to gear the immigration system towards exclusively high-skilled migration were supported by employer associations such as the CBI due to the 'political pressure' and heightened skills shortages (interview with CBI 2015). Drawing on the evidence that growers sourced approximately half of their seasonal labour from the A8 despite A 8 citizens having unrestricted access to the UK labour market, the government's assumption was that British and EU labour would continue to fill these shortages.

The sector was not quite in its opposition to the government's decision to terminate SAWS, often deploying media-related strategies in their lobbying efforts. Meurig Raymond, deputy president of the NFU, said that their members were 'outraged' and that the decision 'completely contradicts David Cameron's belief that farmers are the backbone of Britain' (BBC 2013). In a survey of labour users conducted by the NFU, over $95 \%$ of growers who used SAWS in 2012 said that the removal of the scheme would have a negative impact on their business.

From 2013 to 2016, the government and sector alike adopted a 'wait and see' approach to assess whether the closure of SAWS was proving to effect recruitment. However, the referendum result and the government's preference for a so-called hard Brexit since the result has brought the apparent need for a SAWS back on the agenda. This led the Environmental, Food and Rural Affairs Committee to undertake an inquiry into Brexit and the UK food industry aptly named Feeding the Nation (House of Commons 2017b). The evidence from the sector overwhelmingly indicated that farmers and growers were already struggling to recruit seasonal vacancies despite the fact that free movement was in place. The Committee put this to the Immigration Minister who maintained 'that there is no suggestion that there is a problem .... Nothing has changed' (Goodwill in House of Commons 2017b, p.5). In turn, the Committee concluded that 'we do not share the confidence of the Government that the sector does not have a problem: on the contrary, evidence submitted to this inquiry suggests the current problem is in danger of becoming a crisis if urgent measures are not taken to fill the gaps in labour supply' (House of Commons 2017b). Whether such shortages has been a result of terminating SAWS or a hard Brexit dissuading migrants from entering the UK labour market remains a counterfactual question (host state: labour market).

Agricultural employers have long favoured foreign labour over the British workforce. Such preference is driven by a number of factors, but the overriding determinant is a superior work ethic and other soft skills (Ruhs 2006, 78). In a Home Office study involving 124 interviews with employers across five sectors, only in agriculture did employers unequivocally see migrant workers as 'crucial' to their businesses (Dench et al. 2006, 35). Over a decade later, researchers from Queens University Belfast told the Lords EU Committee that $98 \%$ of the seasonal workforce were migrants from elsewhere in the EU (House of Commons 2017a, 6). It is no exaggeration to say the sector relies on foreign labour.

In 2015, most agricultural employers claimed that it was too early to know the full impacts of closing SAWS on labour shortages, but that the repercussions were likely to be felt long-term (GLA 2014). This was due to the labour supply from Bulgaria and 
Romania 'not immediately drying up' following the closure of SAWS, and due to contingency efforts put in place to ease the transition of the closure including making a limited number of work cards available (interview with NFU 2015). Many in the industry claimed that whilst farms had an adequate workforce for 2014 and 2015, there would be a 'workforce drought' in 2016/2017 (interview HOPS solution 2016; interview Concordia 2015). The NFU's most recent survey of labour providers showed a $17 \%$ drop in seasonal workers, with 1500 vacancies left unfilled in May 2017 alone (NFU 2017). In turn, the industry is reporting a shortfall in workers putting production of crops at risk with the industry calling for a new SAWS (House of Commons 2017a, 3).

The seasonal labour shortages experienced by farmers and growers have potentially large ramifications for the agricultural and horticulture sector as a whole. The value of UK agricultural production (at market prices) was $£ 25.8$ billion in 2014 , and in aggregate, the agri-food sector employs about 3.86 million employees (DEFRA 2016). Whilst reported shortages are of a seasonal nature, in lieu of meeting labour market demands to achieve harvesting produce the wider food production chain is threatened, in turn permanent employees could also be facing job insecurity.

The repercussions of farmers not being able to source enough labour to fill seasonal vacancies extends beyond immigration debates. The implications extend to UK food security. A report from the trade organisation British summer fruits predicted that the cost of strawberries and raspberries could soar by $50 \%$ if Brexit makes it harder for growers to recruit (House of Commons 2017a, b). A survey from British Summer Fruits predicted rising prices of between 35 and $50 \%$ because of labour shortages. Furthermore, a weaker pound as a result of the Brexit uncertainty in the UK economy means imports can possibly cost more.

Yet whether the reliance on EU labour can be said to constitute inevitable structural dependency is debatable. Geddes and Scott (2010) argue that such reliance on migrant workers in the low-skilled sector-such as agriculture - is rather 'constructed'. Drawing on segmented labour market theory (Piore 1979), they claim that it is possible for firms to offset the costs of an uncertain market by 'passing this uncertainty on to certain groups of workers' (Geddes and Scott 2010, 198), in this case seasonal migrant workers. Rogaly (2008) likewise argues that, through mechanisms of intensification, agricultural employers have used vulnerability to ensure compliance in the labour force. Employers' offering poor working conditions then partly construct the dependence on foreign labour in the agricultural sector. Undoubtedly agriculture's reliance on EU workers is of its own making, but path dependency and tight margins with consumers demanding more local produce at cheaper prices has created an intractable structural dependency. To succeed in the long-term, the sector will need to tackle the cycle of 'entrenched use of low-skill, low-paid casual workers' (Delvin 2016).

Working conditions of agricultural workers have not changed in any substantial way since the closure of SAWS, thus attracting British workers to this type of work has remained challenging. British workers are reluctant to engage in this work due to the hard working conditions, long working hours, temporal nature and rural locations. Farm Minister George Eustice suggested in 2014 that UK benefit claimants should be sent to work on farms to fill any vacancies. Yet the seasonal and temporary nature of agricultural work means that there are little incentives for unemployed claimants to return to work for a short period, as the administrative hurdles to reapply for welfare assistance are long; a process which the DWP recognizes does not always support 
smooth transitions from receipt of out-of-work benefits into seasonal work (MAC $2013,160)$. The UK welfare system operates in a way that makes it unfavourable to work for a temporary period.

If British agriculture is to survive the government and more importantly, employers will need to attract and retain British workers as they once did. The closure of SAWS and the loss of EU labour following Brexit uncertainty may create an opportune moment for reforming the welfare system to accommodate seasonal work and potentially for improving pay and working conditions in a sector which has long relied on cheap labour. The government pursued a pilot scheme to fulfill this. The scheme was run by the Department for Work and Pensions was working with JobCentre Plus, LANTRA (the sector skills council) and the NFU to encourage unemployed UK residents into horticultural work through training and guaranteed interviews (Harper 2013). However, these measures seem to have had little to no impact (interview DEFRA 2016). As one interviewee commented: it wasn't very successful and the people that were trained on a course which we worked with, they didn't last in their placements, they worked a few weeks and then they'd leave their jobs, they weren't fulfilling the 6 months. An A2 would've worked that 6 months until the end. I think that proved that the labour can't be used from that welfare to work' (interview HOPS solution 2016). British workers have evidently always been able to work in the agricultural sector, yet they make up less than $10 \%$ of the agricultural labour force and only nine farms in 2013 had any UK employees in temporary/seasonal work, dropping to eight in 2014 (GLA 2014, 6).

There is a clear imperative for the sector to shift towards a generally higher wage and higher skill food system in order to make the work attractive, and the introduction of the National Living Wage in 2016 represents a positive advance. However, the flipside of increasing wages is that they are predicted to impact on tightening profit margins for farmers and growers further. Horticultural crops have an unusually high requirement for seasonal labour, with labour cost often accounting for $35-60 \%$ of business turnover. As a result, the profitability of growing horticultural crops is highly sensitive to changes in wage costs. A report conducted by the NFU $(2016,2)$ assessing the impact of the National Living Wage found that forecasted increases in National Minimum Wage alone are equivalent to $47-58 \%$ of current business profit in the next 5 years. This, the NFU argues, 'has the capacity to make horticultural businesses unprofitable'.

Closing SAWS coupled with Brexit and the loss of EU labour may force the sector to address its rights-based weaknesses in the form of increased wages, better working conditions and reforming upskilling and progression opportunities for British workers. In this sense, the absence of a TMP could prove to be a remedy for the structural dependency and poor working conditions which have traditionally accompanied this sector. Yet the increasingly tight profit margins farmers and growers face as a result of increasing consumer demands and retail demands for lower cost produce, make increasing wages an unappealing solution to the labour crisis the sector faces.

The future opportunity or cost of the lack of an agricultural TMP will ultimately be a shift towards mechanisation, outsourcing and offshoring. On the one hand, automation will improve working conditions for some workers, making manual jobs less labour intensive. On the other hand, technological innovation will drive the automation of all kinds of work and with it bring large-scale job losses, which UKCES predict will lead to an extensive government-led skills programme 
(UKCES 2017, b). Occupations which are most susceptible and likely to be automated in the future are physical (elementary) activities in highly predictable environments. Such moves in agriculture mechanisation have included table-top technology to improve efficiency of the picking process; in salads and brassicas, picking rigs have enabled crops to be picked, washed, processed, packaged, labelled and carted in the field; and in top fruit and stoned fruit, new dwarf varieties of trees have been developed which have greatly eased picking. Whilst such technological developments are long-term solutions and cannot replace current labour-intensive demands, if employers face detrimental labour shortages, the mechanisation of agricultural production may be inevitable.

Whilst the impact on profit margins makes it unlikely, the loss of EU labour in the context of hard Brexit may force the industry to restructure, improve wages and adapt to the new environment (AHDB 2016, 14). Alternatively, and more viable in the longterm, it may drive the sector to look increasingly towards technological solutions and become a fully automated sector to reduce labour dependency. Whilst the latter brings with it opportunities, increases productivity and represents inevitable technological progress, it also brings job displacement including of British workers. This raises major questions for the world of work, skill forecasting, as well as utilitarian or moral questions about the purpose of work (Danaher 2017) and if automation can also become complementary to labour or not.

\section{Sending States}

The second so-called triple wins generated from TMPs are the benefits they bring to the sending states. The most important of these benefits are those concerning remittances and skill transfers. The question then is whether SAWS was a positive gain in development terms for the sending countries, and has the termination and the Brexit uncertainty around EU labour had a negative impact on these countries.

Ruhs $(2006,17)$ argues that the return of immigrants can influence the home society positively in two ways. Firstly, migrant workers transfer skills between states, which are made possible by the return mechanism in place. Secondly, development can occur through businesses or entrepreneurship that are opened with the capital of the returnees. For example, Balaz and Williams (2004) found that, in the case of Slovakian return migrants who had stayed temporarily in the UK, the level of human capital transferred was high. Migration policies including TMPs can also be seen as geopolitical capital and intertwined with trade policy (Peters 2017), as countries forge reciprocal benefits often based on geopolitical ties and/or history. These are typically demonstrated by bilateral agreements, and the majority of youth mobility schemes, including the UK's, are underpinned by reciprocal agreements. SAWS accrued positive diplomatic relations as a side benefit to the scheme:

In terms of international relations it was really strong; the relationships set up particularly between us and Russia - would be really useful at an informal level. On the government side there was a Polish agricultural minister who was exSAWS. So people from SAWS were often people who would achieve in their own country, and achieve influence 
(interview Concordia 2015).

The trade policy potentials for the UK following Brexit could for example act as an opportune moment to forge new relationships with sending states, as Prime Minister's May has endeavored to do in recent visits to China and India. There are further potentials for bilateral deals to be struck with other countries such as Ukraine. In terms of current sending states, emigration central and eastern European countries have already slowed down. This could also mean that there has been saturation in the labour market and emigration levels. In their research, Dustmann and Weiss $(2007,253)$ found that those who return from the UK (in average after 4 to 5 years) are mostly from the EU countries, the Americas and Australia, whilst those who stay are from Indian subcontinent and from Africa. In case of return, the transferability of skills would definitely weigh higher. According to Vertovec (2007), a more ideal way of transferring set of skills is not temporary migration but circular migration if it can be realised.

In terms of the transfer of skills, SAWS was considered a success. As the CBI commented (interview 2015) 'the UK has benefited from those people who are coming to us but also their home country could benefit from either from sending money home or returning.... [we need to] make sure that we have got a system that works as best as it can for everyone. This is not just dividing people into winners and losers'. A high number of SAWS workers returned the following year to generate remittances 'almost as a lifestyle choice' (interview Concordia 2015). As a GLA officer stated in an interview, agricultural work was used as a 'stepping-stone' for many migrant workers and those who had gained the skills could go back and use them in their countries:

Because agriculture was much seen as a stepping-stone for workers with some skills and intelligence to get away from the very basic level of work into something better. So the Polish economy, which I think had 40 per cent unemployment when they came, improved, so anybody who has got skills and ability to be mobile, went back. Not everybody did, large populations in communities of Poles were established and created. But some of them went back with certain skills; others not because people who are already in the country would use the agricultural work as a stepping-stone; the better able workers have left

\section{(Director of Strategy at GLA, interview 2015).}

For repeat season workers especially meant that they could 'take on additional responsibilities, there are supervisor roles, team leader roles, so there's an advantage in that. These are key things for the participants, developing their experience; if they're interested in agriculture they can take their skills back with them as well' (interview Concordia 2015).

Besides skill transfers, remittances are the major contributory factor, which TMPs are said to bring to sending states. Recruiters on SAWS found that 'a lot of people [we]re buying homes in their own countries and people are coming back to make money for that, rather than staying in the UK' (interview HOPS solution 2016). Whilst remittances are an important source of development for sending states from all types of mobility, temporary migration has been found to bring even greater remittances than more permanent migration, precisely because migrant workers intend to return, and thus have high incentives for investing in their 
country of origin (Dustmann and Mestres 2010). Sending emigration is also desired in comparison with permanent emigration by the sending states because those who migrate permanently decrease their remittances over time (ibid). When it comes to temporary migrant workers, the effect of remittances in the sending country Datta et al. (2007) found out that low-paid migrant workers in London have to sacrifice a great deal in their lives in order to send remittances, not only because they are low-paid but in certain cases, sending money to the home country is a strong pressure on the migrant. They suggest that a development policy based on remittances is unethical and unacceptable for the reason that logic of remittances can be another justification for a system that leads to more exploitation (ibid.)

However, a number of studies have found positive advantages of TMPs for sending states. Markova (2010) for example found that Bulgarian returnees from TMPs contributed positively to the Bulgarian economy through an increase of small businesses through remittances. Lucas (2005) argues that consumption in sending states is increased via TMWs' families, which has revived some local economies. For some sending states, the remittances acquired from TMWs provide a main source of income. As one interviewee explained:

The Moldovans as well were sort of saying: we're being shut out. We do what we can to keep Moldovan workers coming to the UK because it's the central income for them - UK wages are 20 to 40 times higher than theirs. So if you've got someone who's a second year student if they could spend six months in the UK then that would fund their studies, so they benefited a lot from that

(NFU policy officer, interview 2011).

Skill transfers acquired are clearly beneficial for both the migrant themselves and their country of origin, and the return clause inherent in TMPs acts as a prevention of brain drain, as the intention is for the worker to return home.

\section{Migrant Rights}

From an ethical perspective, the debate on temporary migrant rights has resulted in three different critical positions. Ruhs and Martin (2008) argues that there is a trade-off in practice between rights and numbers, whilst Mayer (2005) has suggested that some exploitation could be acceptable if the migrant workers are also benefiting from the schemes. In contrast, Lenard and Straehle (2012) argue that there is no need to eliminate the programmes or decrease the numbers but it is possible to improve them by giving the opportunity to migrant workers to have more rights gradually and have a route to permanent residency. If TMPs are to continue, what is the perfect duration of stay to grant the TMWs their political rights and full socio-economic rights? In terms of its contents and qualities, what does a socially just TMP looks like?

The key criticism of TMPs acknowledged by both the NGO and academic sector is the inherent exploitative nature of TMPs. TMPs by their nature are exploitative and too often lead to for a number of reasons: since the work is temporary, the focus is on the 
working process, the work comes first rather than the living conditions, creating bonded labor. Ethically scholars ponder how temporary status can continue for years without gaining further benefits and rights (Hennebry and Preibisch 2012). Prescriptively, integration packages are key to overcome some of the potential exploitation pitfalls; from a local authority perspective it 'does not matter what scheme [migrants] came in on they still need to be able to translate the service information for who is coming throughout the door' (Migration Yorkshire interview 2015).

SAWS was no exception and has been criticised for similar reasons (Anderson and Rogaly 2005). Whilst in law A2, citizens were well protected in contrast to third country nationals, in practice conditions were scarcely better (interview with Unite 2015). A national catastrophe in 2004 highlighted the potentially devastating effect of language barriers, and the potential exploitation of migrant workers, prompting government action to regulate the low-skilled sector. This was the Morecambe Bay Cockling disaster, resulting in the death of 23 Chinese workers. As a result, The Gangmasters Licensing Authority (GLA) (later renamed Gangmasters and Labour Abuse Authority) was established in April 2005, with the primary purpose to prevent the exploitation of workers in the agricultural and food sector. The GLA is a non-departmental public body with a board of 30 members from the industry, unions and government. The GLAA has been heralded as a role model for other countries to prevent exploitation of agricultural labour (interview with GLA, 2014), and there are calls for its remit to be widened (GLA 2015). Some 1201 labour providers had been licensed by the end of 2008, and during this period, 78 licenses were revoked for breaches discovered during inspections.

However, on the absence of a TMP and free mobility, it seems likely that irregular migration will increase. As a Unison interviewee commented:

The other solution is that they stay below the surface and are subject to exploitation, and that's not in their interests and it's not in the interests of other workers because it leads to employers taking on people to exploit them and it leads to undercutting

\section{(Unison interview 2011).}

Whilst this remains circumspect, if farmers and growers cannot source their labour through legitimate channels such as SAWS - which is felt as an inevitability across the sector, as the NFU state 'we know that's coming' (McEwan 2015) - they may 'fall foul of unscrupulous individuals who may commit more serious offences involving illegal labour supply or other potentially more serious criminal offences, for example trafficking or forced labour of the workforce being supplied' (GLA 2014, 30). The GLA $(2014,31)$ also found that additional workers required by farmers or growers were now being sourced through current workers and this presents further risk, as the opportunity is there for unscrupulous and potentially illegal gangmasters to operate within this area and exploit the workforce.

The absence of a TMP in the face of a hard Brexit could be more damaging, since an under-regulated area might become wholly unregulated, and this could have a negative effect on both employers and employees. Coupled with deregulation in the labour market, and not being obliged to abide by international conventions, the rights of 
migrant workers could be further at risk. From an economic liberal perspective, the lack of a TMP could also prevent competition amongst the operators to acquit SAWS work cards. If there is no competition to qualify for attaining SAWS work cards, the operators may lower their standards.

The lack of a holistic package for the migrant workers in the absence of protected EU rights could mean that employers will assume less responsibility. One reason for this is the accommodation clause, which used to be provided by the employers. As employers are not responsible for accommodation this means that the GLA does not have to check the premises of the employers where the migrant workers are staying.

In the long term, the loss of EU labour coupled with the absence of a scheme like SAWS could mean that the migrants who used to come on the basis of SAWS, in which certain standards were guaranteed, will be arriving and working on a more informal basis, and therefore further possibility for exploitation. This would mean that more informal employment and recruitment could take place. Where EU citizens sit within this continuum of rights and entitlements is the looming question.

\section{Concluding remarks}

Throughout the paper, we have underlined that TMPs can be serving a better purpose if they can take into account the agency of the migrant workers. The fact that the TMPs are a triple win can be questioned in many ways as remittances are not a guarantee for development, rights of migrant workers are not always granted fully despite the international conventions on migrant workers' rights (for instance, International Convention on the Protection of the Rights of All Migrant Workers and Members of Their Families) and host countries are not always benefiting from the migrant workers to the utmost level as these migrants do not have the chance to learn how to speak the language and they might be even deskilled doing the temporary jobs.

Therefore, we suggest that in the case of a Brexit, UK will have to face similar dilemmas of bilateral TMPs and the conditions will be determined according to the interests of both states. The bargaining power of the TMPs cannot be balanced as the migrant workers might have to leave the country definitely in case of a contract, unlike the case of the EU citizen migrant workers. Temporariness will be a definite condition as these migrant workers will not be coming from an area of freedom of movement, which means that the European migrant workers will lose most of the rights they had gained in regard to benefiting from visa-free travel and opportunity to seek for jobs. On the other hand, if these programmes are redesigned according to the rights-based perspective, the TMPs can be more beneficial than those such as SAWP in Canada and SAWS in the UK. Until now, TMPs have been falling short of justice considerations, but they are still the only way to manage seasonal work. Thus, we argue that they should not be abandoned but that they should be redesigned so that the unions and migrant advocacy organisations have equal footing with the states, which register and implement these programmes. GLA should assume more responsibilities in the case of a Brexit, that is the only way these programmes can have a better reputation if structured temporariness can ever have such a reputation. Ultimately, the question for policymakers is what does a socially just TMP look like? 
Open Access This article is distributed under the terms of the Creative Commons Attribution 4.0 International License (http://creativecommons.org/licenses/by/4.0/), which permits unrestricted use, distribution, and reproduction in any medium, provided you give appropriate credit to the original author(s) and the source, provide a link to the Creative Commons license, and indicate if changes were made.

\section{References}

Agriculture and Horticulture Development Board [AHDB] (2016). The impact of Brexit on the UK agricultural workforce. https://ahdb.org.uk/documents/Horizon_Brexit_Analysis_20September2016.pdf.

Baláž, V., \& Williams, A. M. (2004). Been there, done that: international student migration and human capital transfers from the UK to Slovakia. Population, Space and Place, 10(3), 217-237.

Bauder, H. (2006). Labor movement: how migration regulates labor markets. Oxford University Press.

BBC (2013). Seasonal agricultural migration scheme scrapped', 12 September. http://www.bbc.co. uk/news/uk-politics 24064774 Accessed on 05 July 2015.

Bernhard, J., Berinstein, C., \& Goldring, L. (2009). Institutionalizing precarious immigration status in Canada. Citizenship Studies, 13(3), 239-265.

Carens, J. (2013). The ethics of immigration. Oxford University Press.

Castles, S. (2006). Back to the future?: can Europe meet its labour needs through temporary migration?. Oxford University: International Migration Institute.

Concordia (2015). Representative Concordia.

Confederation of British Industry [CBI] (2015). Representative Confederation of British Industry.

Cook, J., Dwyer, P., \& Waite, L. J. (2010). The experiences of accession 8 migrants in England: motivations, work and agency. International Migration, 49(2), 54-79.

Danaher, J. (2017). Will life be worth living in a world without work? Technological unemployment and the meaning of life. Science and Engineering Ethics, 23(1), 41-64.

Datta, K., McIlwaine, C., Wills, J., Evans, Y., Herbert, J., \& May, J. (2007). The new development finance or exploiting migrant labour?: remittance sending among low-paid migrant workers in London. International Development Planning Review, 29(1), 43-67.

De Lange, T. and Sarah van W. (2014) Institutionalizing temporary labour migration in Europe: Creating an "Inbetween" migration status. In (eds.) Leah F. Vosko, Preston V. and R. Latham, Liberating temporariness? Migration, work and citizenship in an age of insecurity (pp.126-151). McGill-Queen's University press.

Dench, S., Hurstfield, J., Hill, D., \& Akroyd, K. (2006). Employers' use of migrant labour: main report. London: Home Office.

Department for Environment, Food and Rural Affairs [DEFRA] (2016). British food and farming at a glance. London: DEFRA: https:/www.greaterlincolnshirelep.co.uk/assets/documents/British_food-farmingat_a glance_Defra_21mar_2016.pdf Accessed on 12 November 2017.

Devlin, S. (2016). Agricultural labour in the UK. London: Food Research Collaboration.

Dustmann, C., \& Mestres, J. (2010). Remittances and temporary migration. Journal of Development Economics, 92(1), 62-70.

Dustmann, C., \& Weiss, Y. (2007). Return migration: theory and empirical evidence from the UK. British Journal of Industrial Relations, 45(2), 236-256.

Findlay, A., McCollum, D., Shubin, S., Apsite, E., \& Krisjane, Z. (2013). The role of recruitment agencies in imagining and producing the 'good'migrant. Social \& Cultural Geography, 14(2), 145-167.

Gangmasters Licensing Authority [GLA] (2014). Operation Novalis: GLA consultation on the cessation of the seasonal agricultural workers scheme. http://www.gla.gov.uk/PageFiles/1111/GLA42.15\%20 Operation\%20Novalis\%20Annex\%20A.pdf Accessed on 15 August 2015.

Gangmasters Licensing Authourity [GLA] (2015). Representative Gangmasters Licensing Authourity.

Geddes, A., \& Scott, S. (2010). UK food businesses' reliance on low-wage migrant labour: a case of choice or constraint? In A. Anderson \& M. Ruhs (Eds.), Who needs migrant labour? (pp. 194-215). Oxford: Oxford University Press.

Gilbert, E. (2014) The presence of temporary labour mobility: migrant worker programs across Australia, Canada and New Zealand. In (eds.) Leah F. Vosko, Preston V. and R. Latham, Liberating temporariness? migration, work and citizenship in an age of insecurity (pp. 152-174). McGill- Queen's University Press.

Goldring, L. (2014) Restituting temporariness as the precarity and conditionality of non-citizenship In (eds.) Leah F. Vosko, Preston V. and R. Latham, Liberating temporariness? migration, work and citizenship in an age of insecurity (pp. 218-254). McGill-Queen's University Press.

Goldring, L., \& Landolt, P. (2011). Caught in the work-citizenship matrix: the lasting effects of precarious legal status on work for Toronto immigrants. Globalizations, 8(3), 325-341. 
Gower, M. (2016). Immigration and asylum: changes made by the Coalition Government 2010-2015. London: House of Commons.

Harper, M. (2013). Written Statement to Parliament: Seasonal Agricultural Workers Scheme and the Food Processing Sectors Based Scheme, 12 September. https:/www.gov.uk/government/speeches/seasonalagricultural-workers-scheme-and-the-food-processing-sectors-based-scheme Accessed on 15 August 2015.

Hennebry, J. L., \& Preibisch, K. (2012). A model for managed migration? Re-examining best practices in Canada's seasonal agricultural worker program. International Migration, 50(s1), e19-e40.

HM Government. (2010). The coalition: our programme for government. London: HM Government.

HOPS solution (2016). Representative HOPS Solutions.

House of Commons (2017a). Migrant workers in agriculture. Briefing paper (p. 7987). House of Commons: London.

House of Commons (2017b) Feeding the nation: labour constraints seventh report of session 2016-1. Environment, Food and Rural Affairs Committee.

Horticulture Week (2017). Gove hints at revived Season Agricultural Workers Scheme post-Brexit, 4 October. https:/www.hortweek.com/gove-hints-revived-season-agricultural-workers-scheme-post-brexit/freshproduce/article/1446408 http://www.nfuonline.com/archived-content/more-news/saws-scheme-scrappednfu-statement/.

Labour Providers (2012). Position paper: Seasonal Agricultural Workers Scheme (SAWS) : http://labourproviders.org.uk/wp-content/uploads/2012/11/position_paper-seasonal_agricultural.pdf.

Landolt, P., \& Goldring, L. (2015). Assembling non-citizenship through the work of conditionality. Citizenship Studies, 19(8), 853-869.

Lenard, P. T., and Straehle, C. (2012). Legislated inequality: temporary labour migration in Canada. Toronto and Montreal: McGill-Queen's University Press.

Lucas, R. E. (2005). International migration and economic development: lessons from low-income countries. Edward Elgar Publishing.

Markova, E. (2010). Effects of migration on sending countries: lessons from Bulgaria. Hellenic Observatory Papers on Greece and Southeast Europe. LSE: GreeSE Paper, 35.

Martin, P. (2006). Managing labour migration: temporary worker programmes for the 21 st century. Paper presented at the international symposium on international migration and development, Turin 28-30 June 2006.

Mayer, R. (2005). Guestworkers and exploitation. The Review of Politics, 67(2), 311-334.

McEwan, G. (2015). Minister defends living wage as growers at fruit focus express fear over labour costs' in Horticulture Week. http://www.hortweek.com/minister-defends-living-wage-growers-fruit-focus-expressfear-labour-costs/edibles/article/1358632 Accessed on 6 January 2015.

Migration Advisory Committee [MAC] (2013). Migrant seasonal workers. London: MAC.

Migration Yorkshire (2015). Representative Migration Yorkshire.

National Farmers Union [NFU] (2011). Representative National Farmers Union.

National Farmers Union [NFU] (2015). Representative National Farmers Union.

National Farmers Union [NFU] (2016) End of season survey https://www.nfuonline.com/assets/60835 accessed on 15 th of January 2017.

National Farmers Union [NFU] (2017) Drop in seasonal workers leaves some farms critically short. https://www. nfuonline.com/news/latest-news/drop-in-seasonal-workers-leaves-some-farms-critically-short/.

Peters, M. E. (2017). Trading barriers: immigration and the remaking of globalization. Princeton University Press.

Piore, M. J. (1979). Birds of passage: migrant labour and industrial societies. Cambridge: Cambridge University Press.

Raghuram, P. (2014) Brain circulation or precarious labour? Conceptualising temporariness in the UK's National Health Service. In (eds.) Leah F. Vosko, Preston V. and R. Latham. Liberating Temporariness? Migration, Work and Citizenship in an age of Insecurity (pp.177-200). McGillQueen's University Press.

Rogaly, B. (2008). Intensification of workplace regimes in British horticulture: the role of migrant workers. Population, Space and Place, 14(6), 497-510.

Ruhs, M. (2006). The potential of temporary migration programmes in future international migration policy. International Labour Review, 145(1-2), 7-36.

Ruhs, M., \& Martin, P. (2008). Numbers vs. rights: trade-offs and guest worker programs. International Migration Review, 42(1), 249-265.

Scott, S. (2013). Labour, migration and the spatial fix: evidence from the UK food industry. Antipode, 45(5), 1090-1109.

Simpson, E. (2017) Fruit and veg farmers facing migrant labour shortages, 22 June BBC News: http://www. bbc.co.uk/news/business-40354331 
Spencer, S., Ruhs, M., Anderson, B., \& Rogaly, B. (2007). Migrants' lives beyond the workplace: the experience of central and eastern Europeans in the UK. York: Joseph Rowntree Foundation.

Strauss, K., \& McGrath, S. (2017). Temporary migration, precarious employment and unfree labour relations: exploring the 'continuum of exploitation' in Canada's temporary foreign worker program. Geoforum, 78, 199-208.

Sumption, M. (2017). Labour immigration after Brexit: questions and trade-offs in designing a work permit system for EU citizens. Oxford Review of Economic Policy, 33(suppl_1), S45-S53.

UKCES (2017) The future of work: jobs and skills in 2030. https://www.gov. uk/government/uploads/system/uploads/attachment_data/file/303335/the_future_of_work_key_findings_edit.pdf. Unison (2016). Representative Unison.

Unite (2016). Representative Unite.

Vertovec, S. (2007). Circular migration: the way forward in global policy? Oxford: IMI. 